\title{
Physics-Based Scientific Learning Module to Improve Students Motivation and Results
}

\author{
Soni Nugroho Yuliono*, Sarwanto, Cari \\ Master of Science Education, Sebelas Maret University, Surakarta, Indonesia
}

\begin{tabular}{l}
\hline \hline Article Info \\
\hline Article history: \\
Received Aug 29, 2017 \\
Revised Sep 20, 2017 \\
Accepted Dec 31, 2017 \\
\hline
\end{tabular}

\section{Keywords:}

Motivation to learn Physics module Scientific learning

\begin{abstract}
Teaching materials that available in the school to learn physics especially scientific-based is limited and become one of the obstacles to achieving the learning objectives on electromagnetic waves material. The research aims are to gain scientific Physics-based learning modules for high school grade XII students who have met the eligibility criteria, determine the effectiveness of using scientific-based learning modules Physics to improve motivation and learning outcomes from students of grade XII High School. The development of this research on Physics module using 4D development procedure which consists of the steps of define, design, development, and dissemination. Definition phase consists of the teacher and student's needs analysis process, material analysis, as well as the formulation of the learning module. The design phase of physics learning modules according to the stage of scientific learning is integrated into the module. The development phase consists of the development process of the modules from the design results, validating the feasibility, module revision, limited testing, and the use of scientificallybased learning modules Physics in grade XII IPA 1 Batik 2 Surakarta senior high school. The deployment phase is the deployment process module to another Senior High School in Surakarta. Data Analysis for the study is a quantitative descriptive analysis based on the score criteria and analysis of increasing student motivation through $\mathrm{N}$-gain. Conclusion obtained are; 1) Physics-based scientific learning modules that developed meet the eligibility criteria on aspects of content and presentation, language, the chart, and aspects of learning. The module is declared worthy of the ideals validation results with the percentage of $85.16 \%, 83.66 \%$ by students and teachers in the response phase of the deployment of $85.93 \%$, which is included in the category of "very good"; 2) Physics-based scientific learning modules with material scientific electromagnetic waves can increase students' motivation to gain value 0.4 or in the category "medium".
\end{abstract}

Copyright $\odot 2018$ Institute of Advanced Engineering and Science. All rights reserved.

\section{Corresponding Author:}

Soni Nugroho Yuliono,

Master of Science Education,

Faculty of Education and Teachers, Sebelas Maret University,

Surakarta, 57126 - Indonesia.

Email: Soninugroho23@gmail.com

\section{INTRODUCTION}

Instructional media have a role to assist learners in understanding the concepts of Physics. The results showed the game media could assist learners to understand the concept of Einstein's relativity theory. Romiszowski [1] formulates that learning media can act as messenger from the educators to the receiver (the learner). The module is a teaching material that compiled with easily understood language according to their level of knowledge and age, so they can learn independently. The learners can measure their level of their mastery of the material covered in each unit module [2]. The module has aimed to help and encourage users to learn on their own and not rely on other media [3]. 
Overcome these problems, it is necessary to familiarize the learners to learn independently using the module with scientific learning, so the students are familiar with the scientific attitude. According to [4], science is essential covered three aspects. Science is seen as a process (scientific processes) which means that science is a way to acquire knowledge through some many activities science process skills in an inquiry way, observation and experimentation. Science is seen as the product of (scientific products) which mean that science of systematic form of a collection of facts, concepts, principles, laws, theories, formulas. Science is seen as an attitude (scientific attitudes) means that in the form of values attitudes developed a scientific process. Someone who learn himself and others in the fields of physics, should not choose one of those views. The third view should be selected as a whole so that the learning process can produce highly competent learners.

Good learning success will be achieved if there is a desire to learn. That the desire will arise because of the encouragement (motivation) both in self-learner's or outside the self-learners. Learning motivation for learners is one of the determining factors in achieving the goal, so the greater motivation of the greater success. A Great learner's motivations will have persistent and diligent's effort to achieve the expected goals. Learners with high learning motivation will be even greater learning outcomes are achieved, but students who have low learning motivation achievement of study results also indicated a low [5]. This stage should the role of educators to provide encouragement or motivation that the students have a high passion for studying Physics. Motivation to learn in self-learners not only the responsibility of students, but also the responsibility of educators. Educators can provide motivation through the medium of learning to take care of learners.

This study aimed to obtain scientifically-based learning module on material physics of electromagnetic waves that have met the eligibility criteria and determine effectiveness the of using scientifically-based learning module on material physics of electromagnetic waves to improve student motivation and learning outcomes.

\section{RESEARCH METHOD}

This study is a research development (research and development) that aims to develop scientificbased physics learning modules for motivation and student learning outcomes. The research model is adapted from the model 4-D (four-D model) proposed by [6] includes the step of defining (define), design (design), development (develop), and the deployment phase (disseminate).

Defining phase is done of the student's needs analysis, material analysis, and the formulation of learning. Data collection instruments that used at this stage is the questionnaire analysis of the teachers and student's needs. Selection module format adapted to the format module according to Ministry of National Education and consists of the introduction, contents, and cover. The development phase is done the development of learning of the result of design, product validation, First revision, limited testing, second revision, vast scale trials, third revision. The deployment phase is done by distributing devices that have been developed in other schools. Analysis of data from the assessment sheet at the same stage of this deployment with the analysis of data on the validation phase.

\section{RESULTS OF RESEARCH AND DISCUSSION}

\subsection{Results of Research}

Defining stages involved the literature study and analysis needs. Literature study phase found that the learning tools and infrastructure that teachers have is complete, but not yet have a module as teaching materials, so the teachers use textbooks that have obtained from bookstores or book publishers. Selection of materials based on the results of a literature study National Examination in 2014, showed that in particular the indicator "describes the various types of electromagnetic waves and their use in everyday life" average scores obtained high school students in Surakarta is 53.74, provincial, 61.59, and 66.47 nationwide. It shows the results of learners, especially in these indicators need to be improved. The material presented in the module by loading 1 basic competence of understanding the electromagnetic radiation, the impact on life, and utilization. The analysis results of the student's needs are presented in Table 1. The scientific phase with the module section can be seen in Table 2 .

The development phase (develop), which developed the concept of modules that have been designed at the design stage. Physics learning modules developed using learning materials electromagnetic waves that arranged into two learning activities. First (I) Learning activities contains material spectrum of electromagnetic waves, The Second (II) learning activities contain a materials, electromagnetic wave radiation. Products that have been developed further validated the draft modules by subject matter experts, media specialists, linguists, teachers (reviewer), and peers (peer). Results of expert validation, peer reviewers 
and reviewer of the modules that have been developed as a whole show that the module is fit for use. Module categorized as feasible with an average value of $85.16 \%$ is greater than the natural cut-off score that has a value of $77.70 \%$. Module applied in teaching by 12 students of grade XII. After implementation the learning, the students gave an assessment of the module. Results of assessment of students on average against the legibility of modules on a limited test are 83.66 and included in the category of "Good".

Table 1. Results of Student Needs Analysis

\begin{tabular}{lc}
\hline \multicolumn{1}{c}{ Indicator question } & $(\%)$ \\
\hline To learn by themselves & 31 \\
Fond of reading books & 79 \\
Can understand book that contains the concept of & 93 \\
Physics & \\
Liked learning exerts a problem & 75 \\
The problems discussed are easily found in everyday & 65 \\
life & \\
Learning in a group & 89 \\
Guided by gather information & 82 \\
Guided by analyzing the data & 96 \\
Guidance in making conclusions & 62 \\
Guided in delivering results & 72 \\
Ordinary learn to use the scientific method & 72 \\
Liked Physics book that comes with images, graphics & 100 \\
Full-color display & 31 \\
Modules in printed form & 86 \\
Using standard Indonesian & 58 \\
\hline
\end{tabular}

Table 2. The Scientific Phase with the Module Section

\begin{tabular}{lll}
\hline No & Scientific Step & Rubric in Module \\
\hline 1 & stage Scientific & Disekitar kita \\
2 & Observe Ask & Mengapa? \\
3 & collecting Information & Otak-atik \\
4 & Reasoning & Olah Pikir \\
5 & Communicating & Kumpulan \\
\hline
\end{tabular}

Large-scale trial conducted with 32 students of grade XII Batik 2 Surakarta senior high school. Learning as much as 2 meetings held. Learning outcomes assessment conducted through pretest and posttest in order to know the value of the improvement. Test questions used in the form of 20 multiple choice questions and 20 questions about the pretest-posttest. The results of the pretest assessment with an average of 62.5 and posts with an average of 92.5. Effective assessment of learners is done by using a questionnaire given to the learners. Observation and questionnaire analysis calculations, the average value of effective learners based on observations of 78.59 and 81.36 is based on a questionnaire. Assessment skills using observation during the learning progress and also use the GCC questionnaire given to the students after learning. Results observation skills assessment, there are three indicators observed were observing, experimenting, and communicate the results. Results of the assessment skills of learners have a number of values per indicator 9.62 with an average of 3.19 and $80.2 \%$ pecentage ideals. If adjusted to the criteria according to [7] then the value is entered in both criteria.

Stage large-scale test was conducted to determine the increase in motivation of learners obtained using motivational assessment instrument in the form of observation and questionnaire responses of learners. The instrument used is an instrument which is adapted ARCS teach developed by [8]. The instrument uses four motivational aspects measured include attention (attention), relevance (relevance), confidence (confidence) and satisfaction (satisfaction). In addition the data increased the motivation of learners were also taken using questionnaire responses of learners are given at the beginning before the end of learning using the module and learning by using modules. The result of the calculation $\mathrm{N}$-gain value learning motivation of learners before and after the learning obtained an increase of 0.4 . According to the criteria of interpretation of the value of $\mathrm{N}$-gain [9], the votes in the category of moderate improvement. The highest increase in aspects of attention and the lowest increase in the aspect of relevance.

The last stage is the spread (disseminate). Spreading is done by sending the module to the respondent Physics teacher from six different schools in Surakarta. Assessment is used to determine the look and readability of Physics module based Scientific. Module obtains a response to the percentage of ideals average of $85.26 \%$ is included in the category fit for use. 


\subsection{Discussion}

The physics-based scientific module aims to increase the motivation of learners in the learning that the material was developed based on the electromagnetic wave development procedures Model 4-D (four D model) [6]. This development procedure consists of four phases, there are the definition of the activities define, design, development, and disseminate. The module is packaged in printed form. The physics-based scientific module is a module that can assist learners in understanding the physics of matter in a scientific way. Modules to be able to increase its motivation, then the module should include some particular characteristics. Characteristic for the development of the module [10] include: self-instruction, selfcontained, stand-alone, adaptive, friendly/familiar.

Physics-based Scientific Feasibility module has been tested through the validation phase which is validated by faculty subject matter experts, linguists, media experts, peers (peer reviewer), and a high school physics teacher (reviewer). Assessment of the quality and feasibility of the module include the feasibility aspects of content, appropriateness and feasibility of presenting language. Rate legibility module obtained by questionnaire legibility modules are assessed by the students after using the module.

The learning activities are organized into a warm-up activity, core activities, and closing activity. Scientific learning activities are translated into activities with details of exploration, elaboration, and confirmation, namely: in the form of activities to observe, ask, gather information, to associate and communicate [11]. Scientific Learning activities encourage students to identify problems on their own, find themselves the necessary information, developing information obtained and then make conclusions. Learning the scientific method has the characteristics, namely: learning centered on the learner, involving science process skills in constructing a concept, involves the cognitive processes of potential in stimulating the development of the intellect and can develop the character of learners.

The use of scientific learning model in this study obtains relevant results with other studies, among others: research conducted by [12] shown that the development of scientific-based Physics module on the static fluid material can enhance critical thinking skills of learners. Each stage of scientific learning with scientifically-based learning model can improve critical thinking skills of learners. Research conducted by [13], concluded that the scientific learning in the learning process makes the learners work together more collaboratively, more active participation, and educating more students are Student Centered.

On research [14] developed a module-based physics problems to improve the ability to think creatively with 4D development methods. The study resulted in Physics module categorized in terms of feasibility of the content, presentation, and language. The study can be developed for research and development model in addition to the $4 \mathrm{D}$ model. In addition to the model development, feasibility review could also be developed further the chart feasibility, and readability. The study suggests that the Physics module can be developed with a model based problems and can enhance creative thinking abilities of learners. Equation Research [14] by researchers in the development of the module is the same procedure using the 4D model development, learning is done by departing from a problem.

On research [15] that approach with modules provides flexibility for distance learning for learners. Learning modules will be more effective because it can be used in the learning the individual, small group, and large group. The module has the advantage that the students can learn at any time and also for learners to evaluate their own learning results. Research by [16] that scientifically-based learning modules developed can improve students' critical thinking skills with a high normalized gain criteria.

The efforts are used to increase the motivation of learning modules developed by giving figures, encouraging competition, gave the repetition, to know the results, give praise and punishment. Assessment of motivation is at attention (attention), relevance (relevance), confidence (confidence) and satisfaction (satisfaction). These aspects can be used to measure the motivation of learners as it has been developed by [8]. This module development stage trials conducted wide scale, accompanied by motivation votes at 32 learners grade XII IPA 1 Batik 2 Surakarta Senior High School. Motivation cannot be observed directly but can be interpreted in a person's behavior. Motivation can be seen from the response of learners in the learning process. Rate motivation using questionnaire instrument responses of learners and the observation sheet of students during the learning process.

Sardiman [17] explains the motivation will encourage someone to do something because the motivation has functions such as: "(1) to encourage people to do, so as a driver or motorcycle that releases energy. The motivation, in this case, is the motor of any activity to be undertaken; (2) determining the direction of action ie, towards the goals to be achieved. Thus the motivation to provide direction and activities that should be done in accordance with the formulation of objectives; (3) select actions that determine the actions of what to do are in harmony in order to achieve the goal, to put aside the deeds are no longer useful for that purpose. "[1] Describes the functions of motivation among other things: encourage behavior or an act. The act of learning will occur if a person has the motivation, as a director, meaning that it 
can be a way to be able to the direction to be achieved, as a driver, serves as an engine for the car. The size of motivation will determine the speed of response of a job.

The assessment results increased motivation of observation and assessment questionnaires obtained the highest score on aspects of attention. This is because the aspects of attention is easily done by learners. The value of the initial questionnaire motivation and value questionnaire late motivation to experience the difference. That difference is the motivation of the final value is greater than the value of the initial motivation. The result of the calculation $\mathrm{N}$-gain value learning motivation of learners before and after learning that the value of $\mathrm{N}$-gain of 0.4. According to the criteria of interpretation of the value of $\mathrm{N}$-gain [9], the votes in the category of moderate improvement so that it can be stated that the motivation of learners increased after a given learning by using scientific-based Physics module. Observed values have a relationship with the value of the questionnaire that is, the value of observation provide reinforcement value obtained from the questionnaire responses of learners. [18] reveals that an effective learning can be evaluated in terms of process and outcome. The data is consistent with the statement [19] states that the effectiveness of learning can be seen by looking at the level of achievement of learning objectives by learners. The effectiveness of learning is the success rate of achievement of learning objectives that can be seen through the mastery of learners.

\section{CONCLUSIONS}

The conclusion of research and development, among others: The modules are developed to be eligible based on the results of expert validation ideals with the percentage of $91.08 \%$. Ratings matter experts include: the suitability of the material with the basic competencies, concepts truth material and use of the facts in the example, contextuality material, suitability presentation of the material in the style of learning, and student interest in the material; validation linguists include: the suitability of the language with the ability of Senior high school, the efficiency of the language uses, communicative, use of spelling, terminology, sentence structure, as well as the consistency of the use of symbols and scientific names / foreign language; media expert validation include: color and font size, layout, presentation, and illustrations. The module is declared worthy of assessment peers (peer) with a percentage of $77.14 \%$ with rating ideals include material components, language, image display, and conformity with the purpose of learning. The module is declared eligible by the practitioner (reviewer) or teacher with a percentage of $83.35 \%$ with aspects ideals feasibility assessment includes a component material, language, image display, and conformity with the purpose of learning. The results of the Feasibility assessment modules are also rated by the students to aspects of legibility readability using a questionnaire module with a percentage of $83.66 \%$, and a response ideals of teachers in the deployment phase is feasible module used with a percentage of $85.93 \%$ ideals.

The module effectively improves learning outcomes seen from the increase in the value pretest and posttest with the work of students exceed the minimum value (KKM). The student's motivation has increased after being given learning module using scientifically-based physics with an increase of 0.4 based on $\mathrm{N}$-gain and included in the category of moderate improvement. Aspects of student motivation highest increase in aspects of attention. The highest value on aspects of attention at 88.75 and the lowest at 80.62 aspects of relevance.

\section{REFERENCES}

[1] Hamalik, Oemar. 2010. Proses Belajar Mengajar. Jakarta: Bumi Aksara

[2] Prastowo, Andi 2011. Panduan Kreatif Membuat Bahan Ajar Inovatif. Jogjakarta: DIVA press.

[3] Hamdani, 2011. Strategi Belajar Mengajar. Bandung: Pustaka Setia.

[4] Carin dan Sund. 1990. Teaching Science Through Discovery. New York: Merrill Publishing Company.

[5] Angkowo, Robertus \& Kosasih, A. 2007. Optimalisasi Media Pembelajaran Mempengaruhi Motivasi, Hasil Belajar Dan Kepribadian. Jakarta: PT Grasindo.

[6] Thiagarajan, S et al. 1974. Instructional Development for Training Teachers of Exceptional Children. Minneapolis: Indiana University.

[7] Suwardi, S. 2009. Penelitian Tindakan Kelas (PTK) dan Penulisan Karya Ilmiah. Surakarta: Panitia Sertifikasi Guru Rayon 13.

[8] Keller. 2006. The ARCS Model: Attention, Relevance, Confidence, and Satisfaction. Tersedia pada:http://sphweb.bumc.bu.edu/otlt/teachingLibrary/Learning\%20Theory/ARCSintegrated_handout.pdf

[9] Hake, R.R. 1998. Interactive Engagement Versus Traditional Method: A Six-Thousand Student Survey of Mechanics Test Data for Introductory Phyics Course. Am. J. Phus. 66: 64-74.

[10] Depdiknas. 2008. Teknik Penyusunan Modul. Jakarta: Direktorat Jenderal Manajemen Pendidikan Dasar dan Menengah, Departemen Pendidikan Nasional.

[11] Hosnan, M. 2014. Pendekatan Saintifik dan Kontekstual dalam Pembelajaran Abad 21. Bogor: Penerbit Ghalia Indonesia 
[12] Puspitasari, D. Y. 2014. Pengembangan Modul Fisika Berbasis Scientific Pada Materi Fluida Statis untuk Meningkatkan Keterampilan Berpikir Kritis. Prosiding Seminar Nasional Pendidikan Sains.

[13] Ryberg, Thomas. 2010. Implementation of Scientific Approach for Activities Laboratory, Journal Paedagogy. Vol 32 (45-68). www.ebscohost.com

[14] Festiana, I., Sarwanto \& Sukarmin. 2014. Pengembangan Modul Fisika Berbasis Masalah Pada Materi Listrik Dinamis Untuk Meningkatkan Kemampuan Berpikir Kreatif Siswa SMA. Jurnal Inkuiri, 3 (2), 36-47.

[15] Sejpal, K. 2013. Modular Method of Teaching. International Journal of Research in Education. 2: 169-171.

[16] Darmawan, M. I. 2016. Pengembangan Modul Pembelajaran Fisika Berbasis Saintifik untuk Meningkatkan Keterampilan Berfikir Kritis Siswa SMA/MA. Tesis: Universitas Sebalas Maret.

[17] Sardiman, A.M. 2010. Interaksi dan Motivasi Belajar Mengajar. Jakarta: Rajawali Pers.

[18] Sudjana, Nana \& Ahmad Rivai. 2002. Media Pengajaran. Bandung: Sinar Baru Algesindo.

[19] Uno, Hamzah. 2008. Teori Motivasi dan Pengukurannya. Jakarta. Bumi Aksara. 